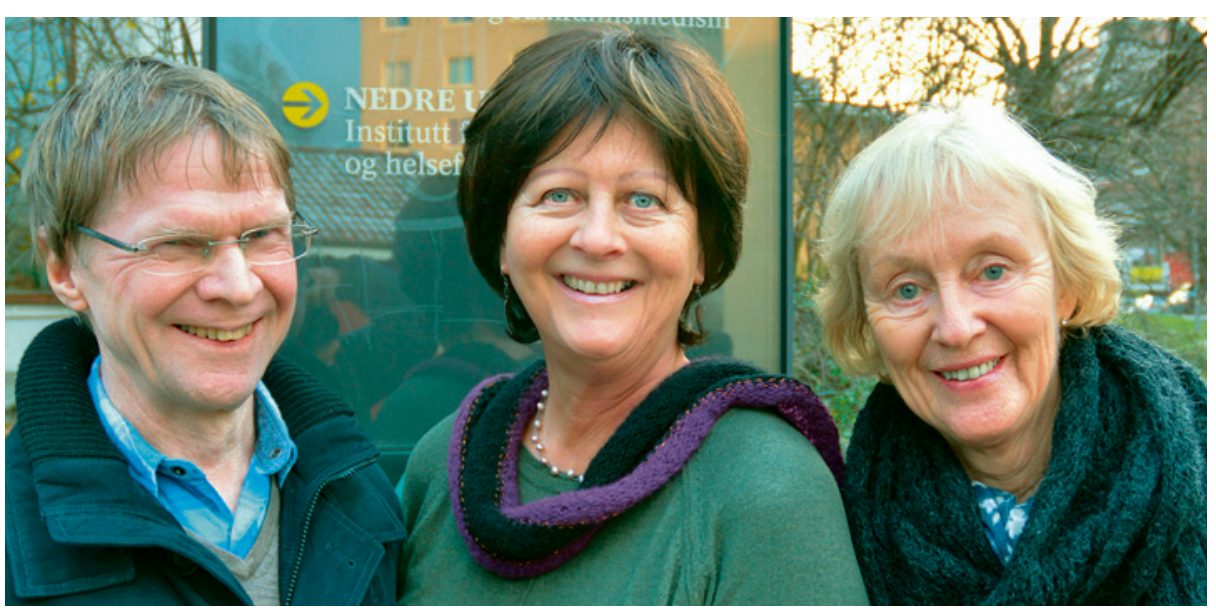

Per Lagerløv, Kirsten Valebjørg Knutsen og Mette Brekke. Foto: Per Hjortdahl

\title{
D-vitamin reduserer ikke smerter
}

\author{
Tilskudd av D-vitamin gir ikke mindre muskel- og skjelettsmerter \\ og hodepine enn placebo. Det viser en ny norsk studie.
}

Flere studier har vist at det er en sammenheng mellom lavt vitamin D-nivå, muskelog skjelettsmerter og hodepine. Innvandrere fra Sør-Asia, Midtøsten og Afrika som bor i Nord-Europa har ofte lave D-vitaminnivåer og mer smerter enn den øvrige befolkningen. I en norsk studie som nylig er publisert i tidsskriftet Pain, har man undersøkt om tilskudd av D-vitamin kan gi mindre muskel- og skjelettsmerter og hodepine (1).

Rundt 250 friske personer $i$ alderen 18-50 år med bakgrunn fra Sør-Asia, Midtøsten og Afrika ble randomisert til tre grupper. Hver gruppe fikk 16 ukers tablettbehandling med enten $25 \mu \mathrm{g}$ eller $10 \mu \mathrm{g}$ vitamin $\mathrm{D}_{3}$ eller placebo. Ved studiestart og etter 16 uker ble det tatt blodprøver, og deltakerne ble spurt om de hadde hatt smerter de siste to ukene, hvor smerten eventuelt var lokalisert og hvor sterk smerten var, bedømt på en visuell analog skala. De som anga at de hadde hatt hodepine de siste fire ukene, fylte også ut et validert skåringsskjema for hodepine.

Deltakerne hadde som gruppe lave $25(\mathrm{OH}) \mathrm{D}_{3}$-nivåer, med en gjennomsnittsverdi på $27 \mathrm{nmol} / 1$ (anbefalt verdi er $>50$ $\mathrm{nmol} / \mathrm{l})$. I placebogruppen var det ingen endring i $25(\mathrm{OH}) \mathrm{D}_{3}$-nivået i løpet av studieperioden, mens hos dem som fikk $10 \mu \mathrm{g}$ eller $25 \mu \mathrm{g}$ vitamin $\mathrm{D}_{3}$, økte $25(\mathrm{OH}) \mathrm{D}_{3}$ nivået til gjennomsnittsverdier på henholdsvis $43 \mathrm{nmol} / \mathrm{l}$ og $53 \mathrm{nmol} / \mathrm{l}$. Ved studiestart hadde $93 \%$ av deltakerne hatt smerter de siste to ukene og $63 \%$ hadde hatt hodepine de siste fire ukene. Etter 16 uker var det en generell bedring når det gjaldt smerte og hodepine, men det var ingen forskjell mellom dem som fikk vitamin D-tilskudd og dem som hadde fått placebo.
- Vår studie viste altså ingen effekt av vitamin D-tilskudd på smerter og hodepine sammenliknet med placebo, sier Kirsten Valebjørg Knutsen, som er artikkelens førsteforfatter. - Den generelle reduksjonen vi så i smerter og hodepine i løpet av studieperioden, kan skyldes placeboeffekten eller det å delta i et forskningsprosjekt. Det er også sett $i$ andre studier at første smertemåling gir høyere skår enn senere målinger, sier hun.

- Men man kan også tenke seg at ytre faktorer, for eksempel økende mengder dagslys gjennom studieperioden (som gikk fra vinter til vår), kan være en årsak til mindre smerte, sier Knutsen.

\section{Allmennmedisinsk forskning}

Kirsten Valebjørg Knutsen er doktorgradsstipendiat ved Avdeling for allmennmedisin ved Institutt for helse og samfunn ved Universitetet i Oslo. Denne artikkelen er del av hennes doktorgradsarbeid. Knutsens interesse for feltet ble vakt gjennom allmennpraksiserfaring med en multietnisk populasjon med høy prevalens av vitamin Dmangel der mange anga at de fikk mindre smerter etter vitamin D-behandling. Per Lagerløv og Mette Brekke er Knutsens veiledere. Studien er gjennomført i samarbeid med Haakon E. Meyer og Ahmed A. Madar ved Avdeling for samfunnsmedisin og Lars C. Stene ved Folkehelseinstituttet.

\section{Lise Mørkved Helsingen \\ Tidsskriftet}

\section{Litteratur}

1. Knutsen KV, Madar AA, Brekke M et al. Effect of vitamin $D$ on musculoskeletal pain and headache: A randomized, double-blind, placebo-controlled trial among adult ethnic minorities in Norway. Pain 2014; 155: 2591-8.
Ordforklaringer

Vitamin D: Dette er et fettløselig vitamin som finnes $i$ to former (vitamin $D_{3}$ og vitamin $D_{2}$ ). Vitamin $D_{3}$ dannes ved hjelp av UV-B-stråler fra solen som transformerer 7-dehydrokolesterol i huden til vitamin $D_{3}$, men det finnes også i fet fisk og enkelte berikede matvarer. Vitamin $D_{2}$ dannes ved UV-bestråling av sopp/gjær og brukes ikke til å berike matvarer i Norge. I leveren omdannes vitamin D til 25(OH)D, som er et forstadium til aktivt vitamin $\mathrm{D}(1,25$ (OH)D). 25(OH)D brukes som et mål på vitamin D-nivået.

Visuell analog skala (VAS): En skala fra 0 til 10 som brukes både klinisk og i forskning for å måle grad av smerte. 0 er ingen smerte og 10 er verst tenkelige smerte.

The Headache Impact Test (HIT-6): Dette er et spørreskjema som brukes for å måle hvordan hodepine påvirker livskvaliteten. tet innen anestesiologi 